Article

\title{
Are Juglans neotropica Plantations Useful as a Refuge of Bryophytes Diversity in Tropical Areas?
}

\author{
Jefferson Medina ${ }^{1,+}$, Wilson Quizhpe ${ }^{2}$, Jorge Déleg ${ }^{1}{ }^{(D}, K_{\text {arina Gonzalez }}^{3}$, Zhofre Aguirre ${ }^{4}$, Nikolay Aguirre ${ }^{4}$, \\ Luis Montaño ${ }^{5}$ and Ángel Benítez $1,6, *,+$ (D)
}

1 Maestría en Biología de la Conservación y Ecología Tropical, Universidad Técnica Particular de Loja, San Cayetano s/n, Loja 1101608, Ecuador; jeffersonmedinabenitez@gmail.com (J.M.); jorgo31@hotmail.com (J.D.)

2 Docente Investigador, Facultad de Ciencias de la Vida, Universidad Estatal Amazónica Sede El Pangui, El Pangui 190401, Ecuador; wr.quizhpec@uea.edu.ec

3 Carrera de Ingeniería Forestal, Universidad Nacional de Loja, Loja 110111, Ecuador; karogonzalezvaldiviezo@gmail.com

4 Docente Investigador, Universidad Nacional de Loja, Loja 110111, Ecuador; zhofre.aguirre@unl.edu.ec (Z.A.); nikolay.aguirre@gmail.com (N.A.)

5 Titulación en Gestión Ambiental, Universidad Técnica Particular de Loja, San Cayetano s/n, Loja 1101608, Ecuador; luis46vr58@gmail.com

6 Biodiversidad de Ecosistemas Tropicales-BIETROP, Herbario HUTPL, Departamento de Ciencias Biológicas, Universidad Técnica Particular de Loja, San Cayetano s/n, Loja 1101608, Ecuador

* Correspondence: arbenitez@utpl.edu.ec

+ Co-first author, these authors contributed equally to this work.

check for updates

Citation: Medina, J.; Quizhpe, W.; Déleg, J.; Gonzalez, K.; Aguirre, Z.; Aguirre, N.; Montaño, L.; Benítez, Á. Are Juglans neotropica Plantations Useful as a Refuge of Bryophytes Diversity in Tropical Areas? Life 2021, 11, 434. https://doi.org/ 10.3390/life11050434

Academic Editors: David Draper and Cecília Sérgio

Received: 30 April 2021

Accepted: 10 May 2021

Published: 12 May 2021

Publisher's Note: MDPI stays neutral with regard to jurisdictional claims in published maps and institutional affiliations.

Copyright: (c) 2021 by the authors. Licensee MDPI, Basel, Switzerland. This article is an open access article distributed under the terms and conditions of the Creative Commons Attribution (CC BY) license (https:// creativecommons.org/licenses/by/ $4.0 /)$.

\begin{abstract}
Neotropical montane forests are considered biodiversity hotspots, where epiphytic bryophytes are an important component of the diversity, biomass and functioning of these ecosystems. We evaluated the richness and composition of bryophytes in secondary successional forests and mixed plantations of Juglans neotropica. In each forest type, the presence and cover of epiphytic bryophytes was registered in 400 quadrats of $20 \mathrm{~cm} \times 30 \mathrm{~cm}$. We analyzed the effects of canopy openness, diameter at breast height (DBH) and forest type on bryophyte richness, using a generalized linear model (GLM), as well as the changes in species composition using multivariate analysis. Fifty-five bryophyte species were recorded, of which 42 species were in secondary forests and 40 were in mixed plantations. Bryophyte richness did not change at forest level; however, at tree level, richness was higher in the mixed plantation of J. neotropica compared to the secondary forests, due to the presence of species adapted to high light conditions. On the other hand, bryophyte communities were negatively affected by the more open canopy in the mixed plantation of J. neotropica, species adapted to more humid conditions being less abundant. We conclude that species with narrow microclimatic niches are threatened by deforestation, and J. neotropica plantations do not act as refuge for drought-sensitive forest species present in secondary forests.
\end{abstract}

Keywords: montane forest; epiphyte; canopy openness; richness; deforestation

\section{Introduction}

Neotropical forests are the most diverse in the world, occupying an area of about 48 million hectares, approximately $50 \%$ of which are located in South America [1]. A large part of this diversity is located in the Andean montane or cloud forests [2,3]. Ecuador is country with the second largest area of this type of forest in South America (11,200,000 ha), of which only 1,448,700 hectares are protected [4], despite being considered biodiversity hotspots [5,6]. These forests support a wide range of biological resources and provide ecosystem services, mainly related to water, climate regulation and carbon capture and storage $[7,8]$.

Ecuador has the highest deforestation rates in South America, estimated at 1.8\% during the 2001-2010 period [9]. By 2008, around 46\% of southern Ecuador's original 
forest cover had been converted into other land use types (e.g., pastures) [10], generating important economic and social consequences [11]. Loss of forest cover, alteration of the hydric balance [12,13], and habitat fragmentation [14] are the main drivers of changes in the composition, structure and functionality of these ecosystems [15,16], determining biodiversity loss [17]. On the other hand, forest plantations occupy about 187 million hectares worldwide, with an annual increase of 4.5 million hectares [18], with South America leading in terms of new planted surface. In Ecuador, especially in the mountainous region (Sierra), pine trees and eucalypts have been widely used for forest plantations $[19,20]$. As a result, areas of primary and secondary forests are surrounded by these anthropized ecosystems, including a few areas with Juglans neotropica plantations.

One of the ecological groups most affected by deforestation are epiphytes (both vascular and non-vascular), because they are very sensitive to environmental changes [21,22]. Epiphytes constitute an essential part of montane forests in terms of diversity and functionality $[21,23,24]$. An important element of this group are the bryophytes, which play a key role in the functioning and balance of ecosystems [25]; because of their physiological and morphological characteristics (poikilohydric organisms), they are narrowly adapted to humidity, solar radiation and temperature conditions, which is why they have become a model group to evaluate forest disturbance [22,26,27].

Forest plantations are anthropized ecosystems widely distributed in the tropical Andes, which is why they have been the subject of different research projects related to flora diversity. Several studies show that diversity decreases drastically in plantations when compared to natural forests [28,29]; however, there are also studies indicating that there are no differences in diversity between primary forests and plantations [30-33], suggesting that organisms respond differently in these anthropized systems [34]. In some tropical areas, the relationship of bryophyte diversity in agroforestry systems has been documented in plantations of Theobroma cacao [35-38] and of the genera Citrus and Mangifera [39]. In addition, research has been carried out in monospecific forests of the genera Polylepis [40,41], Quercus [25,42], Nothofagus [43,44] and Alnus [22], but the role of J. neotropica plantations as reservoirs of bryophyte biodiversity has not been documented to date. Thus, the present research is aimed at comparing for the first time the diversity of epiphytic bryophytes in mixed plantations of $J$. neotropica to secondary montane forests. The hypothesis is based on the observation that more canopy openness in plantations could determine changes in the richness and composition of bryophytes, as has been shown in previous research, comparing agroforestry systems of Theobroma cacao and natural forests [35-38]. To this end, we established the following research questions: (1) Are the richness and composition of bryophyte communities influenced by microclimatic changes (i.e., canopy openness) in plantations and secondary forests? and (2) Can epiphytic bryophytes be used as indicators of J. neotropica plantations?

\section{Materials and Methods}

\subsection{Study Area}

The research was carried out in two types of forest in the Universitary Park "Francisco Vivar Castro" (PUFVC), located south of the city of Loja, $5 \mathrm{~km}$ from the downtown area. The average annual temperature ranges between 15.6 and $16.6^{\circ} \mathrm{C}$; the average annual rainfall is $812.6 \mathrm{~mm}$ /year; the average relative humidity is $71.96 \%$ and the average evaporation is $111.33 \mathrm{~mm}$. The two forest types occupy an approximate area of $22.41 \mathrm{ha}$. The mixed J. neotropica plantation is located in the lower part of the park, at an altitude of 2130 masl (Figure 1), with an area of 0.7 ha. This plantation is approximately 60 years old [45], where no thinning operations have been made, and is characterized by a very uniform structure, the predominant species being J. neotropica, mainly mixed with tree species of Cedrela montana, Siparuna muricata, Inga fendleriana, Vibumum triphyllum, Streptosolen jamesonii, Palicourea heterochroma and Oreopanax rosei [45]. The species is cultivated because it is an important timber species that produces high quality wood [46], and its nuts are edible and used as a colorant in the textile industry [47]. 


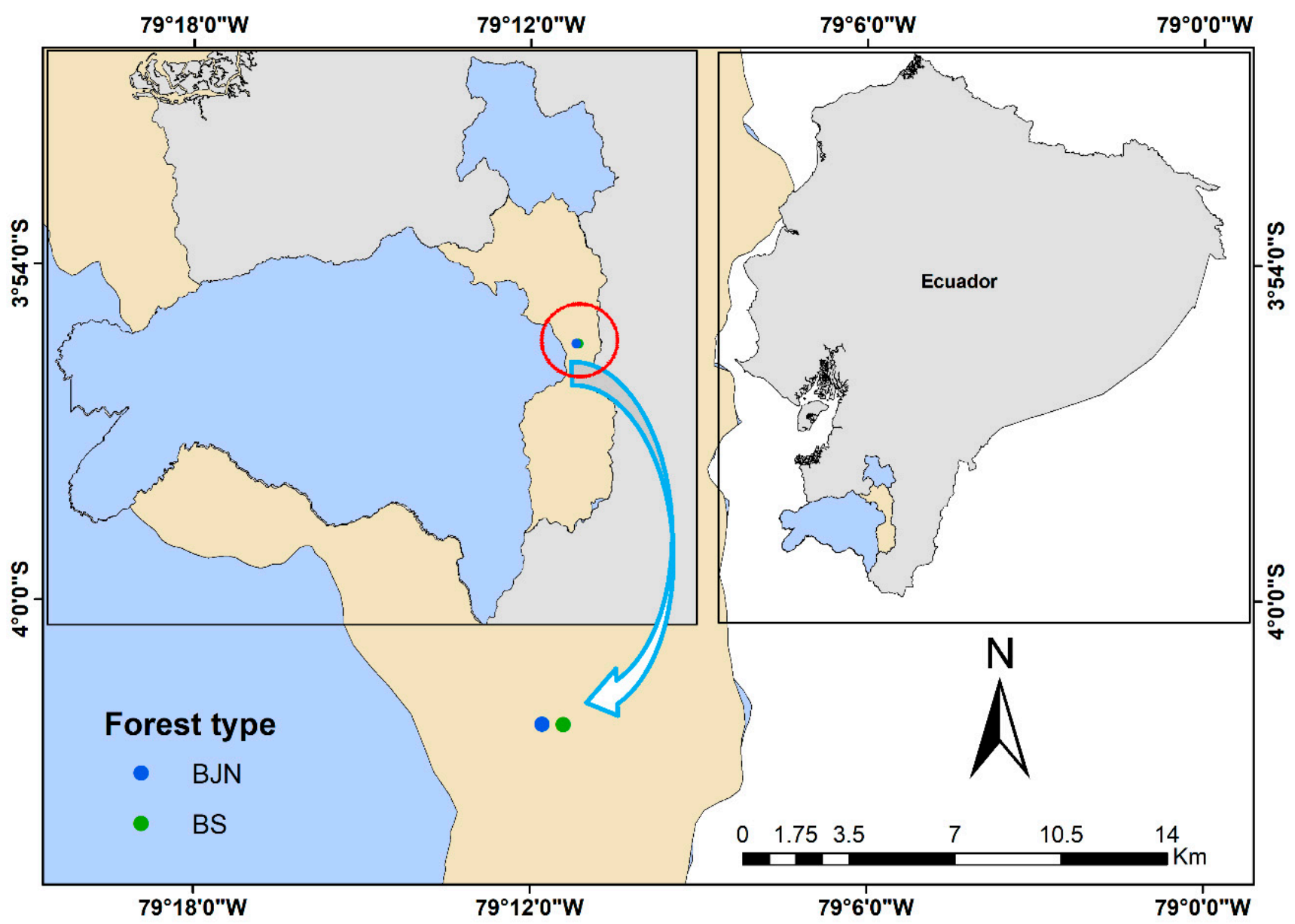

Figure 1. Study area in Loja Province, southern Ecuador, showing the location of the mixed Juglans neotropica plantation and secondary montane forests.

The montane forest is located at an altitude range of 2130-2520 masl, with an area of 99.13 ha and over 60 years of age [48]. The upper canopy is composed of Alnus acuminata, Palicourea amethystina, Phenax laevigatus and Clethra revoluta [48]. The mixed J. neotropica plantation and secondary forests are characterized by the absence of management activities. Fieldwork was carried out between October 2017 and March 2018.

\subsection{Design and Data Collection}

Five $20 \mathrm{~m} \times 20 \mathrm{~m}$ plots were established in each of the two forest types (Table 1); in each plot, 10 trees with a diameter at breast height $(\mathrm{DBH})>10 \mathrm{~cm}$ were selected, for a total of 100 trees. In each tree, the presence and cover of bryophytes was recorded with $20 \mathrm{~cm} \times 30 \mathrm{~cm}$ quadrats established at two heights from the base of the tree (50-100 cm; and 101-200 cm), and two orientations (north and south), for a total of 400 quadrats. The samples were identified in the Herbarium of the Universidad Técnica Particular de Loja (HUTPL), and the Universidad Nacional de Loja (LOJA) using general and specific keys [49-52]. Light conditions were recorded by measuring percent canopy openness, using five digital hemispherical photographs per plot. The distance between photographs within a plot was $5 \mathrm{~m}$. Digital photographs were always taken on overcast days and at breast height $(1.3 \mathrm{~m})$, using a horizontally leveled digital camera (Nikon Coolpix 4500, Nikon, Madrid, España). The hemispheric photographs were analyzed with Gap Light Analyzer (GLA) version 2.0 [53]. 
Table 1. Means of the environmental variables in the studied mixed Juglans neotropica plantation (BJN) and secondary montane forests (BS), with five plots of $20 \mathrm{~m} \times 20 \mathrm{~m}\left(400 \mathrm{~m}^{2}\right)$ within of each forest type in Ecuador. MTD = mean tree diameter.

\begin{tabular}{cccc}
\hline Plot & Forests & Canopy Openess (\%) & MTD (cm) \\
\hline 1 & BJN & 41.76 & 16.92 \\
2 & BJN & 38.02 & 24.08 \\
3 & BJN & 37.96 & 26.47 \\
4 & BJN & 32.11 & 28.40 \\
5 & BJN & 28.61 & 25.32 \\
1 & BS & 21.86 & 17.37 \\
2 & BS & 27.67 & 19.02 \\
3 & BS & 26.56 & 24.17 \\
4 & BS & 26.72 & 19.23 \\
5 & BS & 24.09 & 14.55 \\
\hline
\end{tabular}

\subsection{Data Analysis}

Species diversity in the two forest types was determined by evaluating the specific richness at tree level. Species richness was then analyzed using a generalized linear model (GLM) with a Poisson error distribution and a logarithmic link function [54]. Species composition was visualized using a non-metric multidimensional scaling analysis (NMDS), with the purpose of observing the similarity of bryophyte communities based on the BrayCurtis distance and 999 Monte Carlo permutations. NMDS were conducted using the R package "vegan" [55]. Finally, to analyze the effect of environmental variables as forest type, light and $\mathrm{DBH}$, a correlation between the two fitted axes and the environmental variables was performed with the "envfit" function. To determine which bryophyte species was associated with each forest type, we applied the indicator species analysis [56] using the IndVal function of the "labdsv" package [57]. The indicator value ranges from 0 (the species was absent from one forest type) to 1 (the species occurred in all trees of one forest type and was absent from other trees). All analyses were performed using R statistical software version 3.6.3 [58].

\section{Results}

\subsection{Richness}

A total of 55 species of epiphytic cryptogams (33 genera and 21 families) were recorded (Appendix A). The families with the highest number of species were Lejeuneaceae, Plagiochilaceae, Frullaniaceae and Meteoriaceae. At the forest level, the number of recorded species was similar in the two forest types, with 42 species (18 families and 23 genera) in the montane secondary forest and 41 species in the J. neotropica plantation (17 families and 22 genera). At tree level, the violin plot showed a higher number of species for the mixed J. neotropica plantation compared to secondary montane forests (Figure 2).



Figure 2. Box-plot representing bryophyte richness in the two types of forest: mixed Juglans neotropica plantation (BJN) and montane forests (BS); median richness (black horizontal bars). 
Forest type and DBH had significant positive effects on species richness. The mixed J. neotropica plantation showed the highest coefficients for bryophyte species richness, while the coefficients for secondary forest had the lowest values (Table 2). Conversely, canopy openness showed a significant negative effect on bryophyte richness (Table 2).

Table 2. Results of the generalized linear models showing the effects of forest type (BJN—mixed Juglans neotropica plantation, BS-secondary montane forests), canopy openness and diameter at breast height (DBH) on the richness of epiphytic bryophytes. Coef.—coefficient, ES.-Stardar error $Z$. $-z$ value, $P-p$-value.

\begin{tabular}{ccccc}
\hline & Coef. & ES & $Z$ & $p$-Value \\
\hline BJN & 2.23537 & 0.39043 & 5.725 & $<0.0001$ \\
BS & -0.31825 & 0.12705 & -2.505 & 0.01225 \\
Canopy openness & -0.02284 & 0.01086 & -2.104 & 0.03539 \\
DBH & 0.01085 & 0.00409 & 2.652 & 0.00801 \\
\hline
\end{tabular}

\subsection{Species Composition}

The NMDS ordination showed that the community composition of epiphytic bryophytes is different in the two forest types (Figure 3).

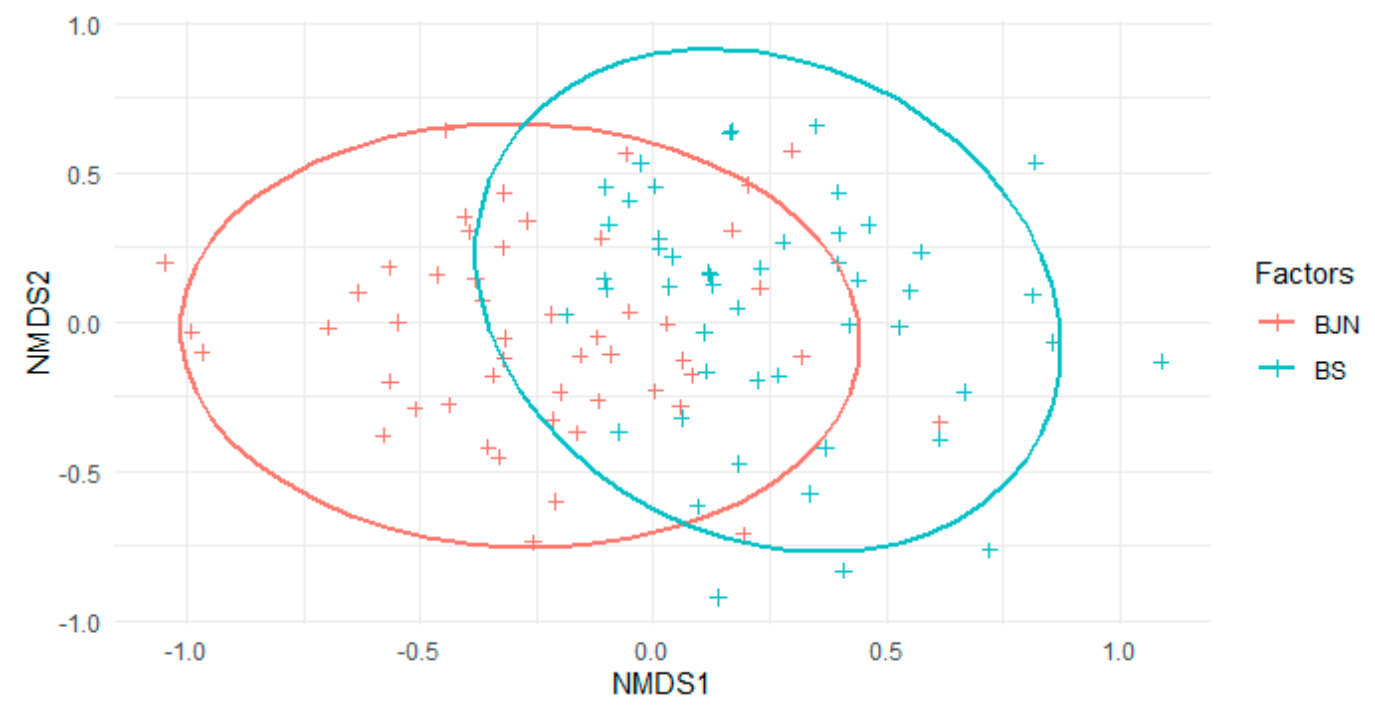

Figure 3. Nonmetric multidimensional scaling analysis ordination plot for the samples (trees) from the two types of forests (BS = Secondary forests; BJN = mixed plantations of Juglands neotropica).

The multivariate statistical analyses showed that epiphytic bryophyte composition was structured according to microclimatic changes, with a large component of variation (i.e., $34 \%$ ) associated with canopy openness, followed by forest type and DBH, with $26 \%$ and $6 \%$, respectively (Table 3 ).

Table 3. Squared correlation coefficients $\left(r^{2}\right)$ fitted on the first two axes of the NMDS ordination for host tree species, host tree traits and environmental factors. BJN-mixed Juglans neotropica plantation, BS—secondary montane forests, DBH—diameter at breast height.

\begin{tabular}{ccccc}
\hline & NMDS1 & NMDS2 & $r^{2}$ & $p$-Value \\
\hline Forests & & & 0.261 & 0.000999 \\
BJN & -0.2736 & -0.0361 & & \\
BS & 0.2792 & 0.0368 & & \\
Canopy openness & -0.94759 & -0.3195 & 0.3426 & 0.000999 \\
DBH & -0.5131 & -0.85833 & 0.0643 & 0.042957 \\
\hline
\end{tabular}




\subsection{Indicator Species}

The analysis of indicator species determined four indicator species in the mixed platation of J. neotropica: Radula tectiloba with indicator value of 58.9, Frullania ericoides with 32, Frullania riojaneirensis with 30 and Lejeunea deplanata with 18, and four species in secondary forests: Plagiochila raddiana with indicator value of 55.5, Porotrichum longirostre with 39.4, Pseudomarsupidium decipiens with 15.5 and Lophocolea bidentata with 13.8.

\section{Discussion}

The results indicate that the richness and composition of epiphytic cryptogams were affected by forest type, mainly due to changes in canopy openness. Similarly, previous studies found an effect of canopy cover on the diversity of epiphytic bryophytes in montane forests $[22,37,38,59,60]$. We recorded a relatively high number of bryophytes in the mixed plantation of J. neotropica (41 species), which is similar to the 51 species reported for Theobroma cacao plantations [30], and higher than the 24 species found in monospecific forests of Alnus acuminata Kunth [26].

Species richness was influenced by forest type, with a higher number of species being recorded in the mixed J. neotropica plantation at the tree level compared with secondary forest. This is mainly due to the fact that the J. neotropica plantation presented more canopy openness compared to the secondary forest, which implies alterations in the microclimate with lower humidity and higher light availability. These changes favored the establishment of sun epiphytes of the genera Frullania, Lejeunea and Radula, which are better adapted to these environments, having functional characteristics adapted to conditions of excess light. Similar to our findings, several studies have documented that disturbed forests have a higher number of sun epiphytes, so the total richness is equal or even increases in disturbed forests when compared to natural forests $[22,25]$. On the other hand, the J. neotropica plantation appeared to be of minor conservation importance for the bryophytes with narrow microclimatic niches (drought-sensitive species: Plagiochila raddiana and Porotrichum longirostre). Similar results have been shown in cacao agroforests [35-38]. In addition, the studied J. neotropica plantation was established around 60 years ago, making it a mixed system with native species from secondary forests, which possibly explains why there is a similar number of species in the two forests. The composition of epiphytic bryophyte communities changes significantly in the secondary forest with respect to the mixed J. neotropica plantation, mainly related to more canopy openness, which is in accordance with several studies carried out in tropical areas [21,22,26,59]. Following the same pattern, the indicator species analysis (ISA) showed that Radula tectiloba, Frullania ericoides and Frullania riojaneirensis are good indicator species for J. neotropica plantations. Corroborating the findings, Acebey et al. [59] and Benitez et al. [26] point out that sun epiphytes are more dominant in secondary or disturbed forests, and they replace shade epiphytes. Thus, Gradstein [51] points out that these species are most common in open woodlands (i.e., drought tolerant epiphytic liverworts).

A different pattern can be seen in the secondary forest, which is characterized by more canopy cover, where the shade epiphytes (e.g., Porotrichum and Plagiochila) were dominant, due to the fact that these forests have higher humidity and less light availability. Thus, Plagiochila raddiana and Porotrichum longirostre were the best indicator species for secondary forests. Corroborating this pattern, several studies have documented that shade epiphytes are restricted to native and secondary forests that provide optimal microclimate conditions $[21,22,25,26,60]$, because these species are sensitive to microclimatic changes due to their need for high humidity levels. In our case, the mixed plantation of J. neotropica presented a higher percentage of light $(33.69 \%)$ that passes to the understory compared to the secondary forest $(25.38 \%)$, which explains the absence of species with higher water needs. Similarly, Sporn et al. [37] and Ariyanti et al. [36] showed singnificant changes in bryophyte composition between cacao agroforests and natural forests, related to microclimatic changes (e.g., canopy cover). Finally, tree diameter had a significant effect on the richness and composition of bryophyte communities, related to increased substrate 
availability for species distribution and establishment. Similar to our results, Guerra et al. [60] and Gradstein and Culmsee [61] found that tree diameter is a key factor for the establishment and distribution of bryophytes in tropical forests, because large trees offer more surface area for the colonization of epiphytic bryophyte communities [26].

\section{Conclusions}

The diversity of bryophytes in mixed plantations of J. neotropica and secondary forests was conditioned by the canopy openness. Although the two habitat types showed a similar total richness at forest level, at tree level a higher richness of bryophytes (especially sun epiphytes) was recorded in the plantations compared with secondary forests. Although older mixed plantations (circa 60 years) of J. neotropica are colonized by native species and have a similar richness of bryophytes compared with secondary forests, these plantations do not harbour communities of species adapted to high humidity conditions in the same way secondary forests can. Since J. neotropica plantations do not provide a refuge for the local epiphytic bryophyte species with narrow microclimatic niches, natural forests are crucial to the conservation of the drought-sensitive forest bryophyte species.

Author Contributions: Conceptualization, J.M., Á.B. and W.Q.; methodology, J.M., Á.B., W.Q. and K.G.; formal analysis, J.M., J.D. and Á.B.; investigation, J.M., K.G., W.Q., N.A., Z.A., J.D., L.M. and Á.B.; writing—original draft preparation, J.M. and Á.B.; writing—review and editing, J.M., K.G., W.Q., N.A., Z.A., J.D., L.M. and Á.B. All authors have read and agreed to the published version of the manuscript.

Funding: This research was funded by Universidad Nacional de Loja and Universidad Técnica Particular de Loja (UTPL-PROY_INV_CCBIO_2020_2773).

Institutional Review Board Statement: Not applicable.

Informed Consent Statement: Not applicable.

Data Availability Statement: Data is contained within the article.

Acknowledgments: We thank Ministerio del Ambiente y Agua del Ecuador by providing access to the study areas and anonymous reviewers for constructive comments on the manuscript. We thank Diana Székely for valuable help with revising the English language.

Conflicts of Interest: The authors declare no conflict of interest.

\section{Appendix A}

Table A1. Number of trees on which each species appears in two types of forests. (BS = Secondary forests; BJN = mixed plantations of Juglans neotropica). * denote threatened species in Ecuador [62].

\begin{tabular}{lcc}
\hline Taxa & Forest of Juglans neotropica (BJN) & Secondary Forests (BS) \\
\hline Liverworts & & \\
\hline Aneuraceae & & 1 \\
$\quad$ Riccardia digitiloba (Spruce) Pagan & 1 & 8 \\
\hline Adelanthaceae & & \\
$\quad$ Pseudomarsupidium decipiens (Hook.) Grolle & 6 & 1 \\
\hline Frullanieaceae & 2 \\
Frullania brasiliensis Raddi & 16 \\
$\quad$ Frullania caulisequa (Nees) Mont. & 15 \\
$\quad$ Frullania ericoides (Nees) Mont. & \\
$\quad$ Frullania riojaneirensis (Raddi) Ångstr. & \\
Frullania subtilissima (Nees ex Mont.) Lindenb. & 1 \\
\hline
\end{tabular}


Table A1. Cont.

\begin{tabular}{|c|c|c|}
\hline Taxa & Forest of Juglans neotropica (BJN) & Secondary Forests (BS) \\
\hline \multicolumn{3}{|l|}{ Lejeuneaceae } \\
\hline Bryopteris filicina (Sw.) Nees & 1 & \\
\hline Cheilolejeunea filiformis (Sw.) W. Ye, R.L. Zhu \& Gradst. & & 1 \\
\hline Dicranolejeunea axillaris (Nees \& Mont.) Schiffn. & 1 & \\
\hline Drepanolejeunea cutervoensis (Loitl.) Grolle & & 1 \\
\hline Frullanoides densifolia Raddi subsp. densifolia. & 1 & \\
\hline Lejeunea cerina (Lehm. \& Lindenb.) Lehm. \& Lindenb. & 9 & 15 \\
\hline Lejeunea deplanata Nees & 9 & \\
\hline Lejeunea flava (Sw.) Nees & 1 & 1 \\
\hline Lejeunea laetevirens Nees \& Mont. & 17 & 12 \\
\hline Lejeunea ramulosa Spruce & 3 & \\
\hline Marchesinia brachiata (Sw.) Schiffner & 1 & \\
\hline Microlejeunea acutifolia Steph. & 1 & \\
\hline Microlejeunea bullata (Taylor) Steph. & & 1 \\
\hline \multicolumn{3}{|l|}{ Lophocoleaceae } \\
\hline $\begin{array}{l}\text { * Leptoscyphus autoicus (J.J. Engel \& Gradst.) Vanderp. } \\
\text { and Gradst. }\end{array}$ & & 1 \\
\hline Lophocolea bidentata (L.) Dumort. & 1 & 7 \\
\hline Lophocolea muricata (Lehm.) Nees & & 4 \\
\hline \multicolumn{3}{|l|}{ Metzgeriaceae } \\
\hline Metzgeria dorsipara (Herzog) Kuwah. & 2 & 1 \\
\hline Metzgeria leptoneura Spruce & 1 & 3 \\
\hline \multicolumn{3}{|l|}{ Plagiochilaceae } \\
\hline Plagiochila aerea Taylor & & 1 \\
\hline Plagiochila bifaria (Sw.) Lindenb. & & 1 \\
\hline Plagiochila cristata (Sw.) Lindenb. & 9 & 4 \\
\hline Plagiochila diversifolia Lindenb. \& Gottsche & 6 & 3 \\
\hline Plagiochila gymnocalycina (Lehm. \& Lindenb.) Mont. and Nees & 2 & 1 \\
\hline Plagiochila raddiana Lindenb. & 29 & 36 \\
\hline \multicolumn{3}{|l|}{ Porellaceae } \\
\hline Porella brachiata (Taylor) Spruce & 2 & 2 \\
\hline Porella crispata (Hook.) Trevis. & 3 & 3 \\
\hline \multicolumn{3}{|l|}{ Radulaceae } \\
\hline Radula episcia Spruce & 3 & 7 \\
\hline Radula gottscheana Taylor & 7 & 8 \\
\hline Radula tectiloba Steph. & 34 & 7 \\
\hline \multicolumn{3}{|l|}{ Mosses } \\
\hline \multicolumn{3}{|l|}{ Bryaceae } \\
\hline Bryum apiculatum Schwägr & & 1 \\
\hline \multicolumn{3}{|l|}{ Calymperaceae } \\
\hline Syrrhopodon incompletus Schwägr. & 7 & 5 \\
\hline \multicolumn{3}{|l|}{ Cryphaeaceae } \\
\hline Cryphaea jamesonii Taylor & 3 & \\
\hline
\end{tabular}


Table A1. Cont.

\begin{tabular}{|c|c|c|}
\hline Taxa & Forest of Juglans neotropica (BJN) & Secondary Forests (BS) \\
\hline \multicolumn{3}{|l|}{ Daltoniaceae } \\
\hline Adelothecium bogotense (Hampe) Mitt. & & 1 \\
\hline \multicolumn{3}{|l|}{ Dicranaceae } \\
\hline Campylopus flexuosus (Hedw.) Brid. & 1 & \\
\hline \multicolumn{3}{|l|}{ Fabroniaceae } \\
\hline Fabronia ciliaris (Brid.) Brid. & 1 & \\
\hline \multicolumn{3}{|l|}{ Meteoriaceae } \\
\hline Meteoridium remotifolium (Müll. Hal.) Manuel & 6 & 5 \\
\hline Squamidium leucotrichum (Taylor) Broth. & 3 & 5 \\
\hline Squamidium nigricans (Hook.) Broth. & 2 & 3 \\
\hline Zelometeorium recurvifolium (Hornsch.) Manuel & & 13 \\
\hline \multicolumn{3}{|l|}{ Mniaceae } \\
\hline Plagiomnium rhynchophorum (Hook.) T.J. Kop. & & 1 \\
\hline \multicolumn{3}{|l|}{ Neckeraceae } \\
\hline Neckeropsis undulata (Hedw.) Reichardt & 12 & 11 \\
\hline Porotrichum filiferum Mitt. & & 4 \\
\hline Porotrichum longirostre (Hook.) Mitt. & 15 & 26 \\
\hline \multicolumn{3}{|l|}{ Orthotrichaceae } \\
\hline Macromitrium richardii Schwägr. & 2 & \\
\hline \multicolumn{3}{|l|}{ Sematophyllaceae } \\
\hline Acroporium pungens (Hedw.) Broth. & 1 & 2 \\
\hline Sematophyllum subsimplex (Hedw.) Mitt. & 14 & 7 \\
\hline \multicolumn{3}{|l|}{ Thuidiaceae } \\
\hline Thuidium peruvianum Mitt. & 35 & 25 \\
\hline Thuidium tomentosum Schimp. & 2 & 2 \\
\hline
\end{tabular}

\section{References}

1. Kapos, V.; Rhind, J.; Edwards, M.; Price, M.F.; Ravilious, C. Developing a map of the world's mountain forests. In Forests in Sustainable Mountain Development: A State-of Knowledge Report for 2000; Price, M.F., Butt, N., Eds.; CAB International: Wallingford, UK, 2000; pp. 4-12.

2. Antonelli, A.; Sanmartín, I. Why are there so many plant species in the Neotropics? Taxon 2011, 60, 403-414. [CrossRef]

3. Lagomarsino, L.P.; Condamine, F.L.; Antonelli, A.; Mulch, A.; Davis, C.C. The abiotic and biotic drivers of rapid diversification in Andean bellflowers (Campanulaceae). New Phytol. 2016, 210, 1430-1442. [CrossRef] [PubMed]

4. Brown, A.D.; Kappelle, M. (Eds.) Introducción a los bosques nublados del neotrópico: Una síntesis regional. In Bosques Nublados del Neotrópico; INBio: San Jose, Costa Rica, 2001; pp. 25-40.

5. Churchill, S.P.; Balslev, H.; Forero, E.; Luteyn, J.L. Biodiversity and conservation of neotropical montane forests. In Proceedings of the Neotropical Montane Forest Biodiversity and Conservation Symposium, Bronx, NY, USA, 21-26 June 1993.

6. Myers, N.; Mittermeier, R.A.; Mittermeier, C.G.; Da Fonseca, G.A.; Kent, J. Biodiversity hotspots for conservation priorities. Nature 2000, 403, 853. [CrossRef] [PubMed]

7. Cuesta, F.; Peralvo, M.; Valarezo, N. Los Bosques Montanos de los Andes Tropicales: Una Evaluación Regional de su Estado de Conservación y de su Vulnerabilidad a Efecto del Cambio Climático; Serie Investigación y Sistematización; Imprenta Mariscal: Quito, Ecuador, 2009.

8. Tejedor, G.N.; Álvarez, E.; Arango, C.S.; Araujo, M.A.; Blundo, C.; Boza, E.T.E.; La Torre, C.M.A.; Gaviria, J.; Gutiérrez, N.; Jørgensen, P.M.; et al. Evaluación delo estado de conservación de los bosques montanos en los Andes tropicales. Rev. Ecos. 2012, $21,148-166$.

9. Food and Agriculture Organization of the United Nations. State of the Word's Forest; Food and Agriculture Organization of the United Nations: Roma, Italy, 2011; p. 117.

10. Tapia-Armijos, M.F.; Homeier, J.; Espinosa, C.I.; Leuschner, C.; De la Cruz, M. Deforestation and forest fragmentation in South Ecuador since the 1970s—Losing a hotspot of biodiversity. PLoS ONE 2015, 10, e0133701. [CrossRef] [PubMed] 
11. Laurance, W.F. Reflections on the tropical deforestation crisis. Biol. Conserv. 1999, 91, 109-117. [CrossRef]

12. Whitmore, T.; Sayer, J. Deforestation and species extinction in Tropical Forest. In Tropical Deforestation and Species Extinction; IUCN: Gland, Switzerland; Chapman and Hall: London, UK, 1992.

13. Whitmore, T. Tropical forest disturbance, disappearance, and species loss. In Tropical Forest Remnants: Ecology, Management, and Conservation of Fragmented Communities; University of Chicago Press: Chicago, IL, USA, 1997; pp. 3-12.

14. Cayuela, L. Deforestación y fragmentación de bosques tropicales montanos en los Altos de Chiapas, México. Efectos sobre la diversidad de árboles. Ecosistemas 2006, 15, 192-198.

15. Saunders, D.A.; Hobbs, R.J.; Margules, C.R. Bilogical consequences of ecosystem fragmentation: A review. Conserv. Biol. 1991, 5, 18-32. [CrossRef]

16. Debinski, D.M.; Holt, R.D. A Survey and Overview of Habitat Fragmentation Experiments. Conserv. Biol. 2000, 14, 342-355. [CrossRef]

17. Brooks, T.M.; Mittermeier, R.A.; Mittermeier, C.G.; Da Fonseca, G.A.B.; Rylands, A.B.; Konstant, W.R.; Flick, P.; Pilgrim, J.; Oldfield, S.; Magin, G.; et al. Habitat Loss and Extinction in the Hotspots of Biodiversity. Conserv. Biol. 2002, 16, 909-923. [CrossRef]

18. Carle, J.; Vuorinen, P.; Del Lungo, A. Status and trends in global forest plantation development. For. Prod. J. 2002, 52, 12-23.

19. Knoke, T.; Bendix, J.; Pohle, P.; Hamer, U.; Hildebrandt, P.; Roos, K.; Gerique, A.; Sandoval, M.L.; Breuer, L.; Tischer, A.; et al. Afforestation or intense pasturing improve the ecological and economic value of abandoned tropical farmlands. Nat. Commun. 2014, 5, 5612. [CrossRef]

20. Quichimbo, P.; Jiménez, L.; Veintimilla, D.; Tischer, A.; Günter, S.; Mosandl, R.; Hamer, U. Forest Site Classification in the Southern Andean Region of Ecuador: A Case Study of Pine Plantations to Collect a Base of Soil Attributes. Forests 2017, 8, 473. [CrossRef]

21. Gradstein, S.R. Epiphytes of tropical montane forests-impact of deforestation and climate change. In The Tropical Mountain Forest, Patterns and Processes in a Biodiversity Hotspot; Gradstein, S.R., Homeier, J., Gansert, D., Eds.; University Press: Göttingen, Germany, 2008; pp. 51-65.

22. Nöske, N.M.; Hilt, N.; Werner, F.A.; Brehm, G.; Fiedler, K.; Sipman, H.J.; Gradstein, S.R. Disturbance effects on diversity of epiphytes and moths in a montane forest in Ecuador. Basic Appl. Ecol. 2008, 9, 4-12. [CrossRef]

23. Barthlott, W.; Schmit-Neuerburg, V.; Nieder, J.; Engwald, S. Diversity and abundance of vascular epiphytes: A comparison of secondary vegetation and primary montane rain forest in the Venezuelan Andes. Plant Ecol. 2001, 152, 145-156. [CrossRef]

24. Krömer, T.; García-Franco, J.G.; Toledo-Aceves, T. Epífitas vasculares como bioindicadores de la calidad forestal: Impacto antrópico sobre su diversidad y composición. In Bioindicadores: Guardianes de Nuestro Futuro Ambiental; González, C.A., Va-llarino, A., Pérez, J.C., Low, A., Eds.; Instituto Nacional de Ecología y Cambio Climático (INECC): Chiapas, Mexico, 2014 ; pp. 605-623.

25. Holz, I.; Gradstein, R.S. Cryptogamic epiphytes in primary and recovering upper montane oak forest of Costa Rica-Species richness, community composition and ecology. Plant Ecol. 2005, 178, 89-109. [CrossRef]

26. Benítez, A.; Prieto, M.; Aragón, G. Large trees and dense canopies: Key factors for maintaining high epiphytic diversity on trunk bases (bryophytes and lichens) in tropical montane forests. Forestry 2015, 88, 521-527. [CrossRef]

27. Alvarenga, L.D.P.; Pôrto, K.C. Patch size and isolation effects on epiphytic and epiphyllous bryophytes in the fragmented Brazilian Atlantic forest. Biol. Conserv. 2007, 134, 415-427. [CrossRef]

28. Calviño-Cancela, M.; de Silanes, M.E.L.; Rubido-Bará, M.; Uribarri, J. The potential role of tree plantations in providing habitat for lichen epiphytes. For. Ecol. Manag. 2013, 291, 386-395. [CrossRef]

29. Ríos, A.I.A.; Moncada, B.; Lücking, R. Epiphyte homogenization and de-diversification on alien Eucalyptus versus native Quercus forest in the Colombian Andes: A case study using lirellate Graphidaceae lichens. Biodivers. Conserv. 2015, 24, 1239-1252. [CrossRef]

30. González-Montelongo, C.; Pérez-Vargas, I. Looking for a home: Exploring the potential of epiphytic lichens to colonize tree plantations in a Macaronesian laurel forest. For. Ecol. Manag. 2019, 453, 117541. [CrossRef]

31. Goded, S.; Ekroos, J.; Domínguez, J.; Azcárate, J.G.; Guitián, J.A.; Smith, H.G. Effects of eucalyptus plantations on avian and herb species richness and composition in North-West Spain. Glob. Ecol. Conserv. 2019, 19, e00690. [CrossRef]

32. Tavares, A.; Beiroz, W.; Fialho, A.; Frazão, F.; Macedo, R.; Louzada, J.; Audino, L. Eucapyptus plantations as hybrid ecosystems: Implication for species conservation in the Brazilian Atlantic. For. Ecol. Manag. 2019, 433, 131-139. [CrossRef]

33. González-Montelongo, C.; Pérez-Vargas, I. Is an invasive alien tree able to sustain a similar lichen diversity as the native forest? The case of the sweet chestnut (Castanea sativa Mill.) and the laurel forest in Macaronesia. For. Ecol. Manag. 2021, 488, 119009. [CrossRef]

34. Stephens, S.S.; Wagner, M.R. Forest plantations and biodiversity: A fresh perspective. J. For. 2007, 105, $307-313$.

35. Andersson, M.S.; Gradstein, S.R. Impact of management intensity on non-vascular epiphyte diversity in cacao plantations in western Ecuador. Biodivers. Conserv. 2005, 14, 1101-1120. [CrossRef]

36. Ariyanti, N.S.; Bos, M.M.; Kartawinata, K.; Tjitrosoedirdjo, S.S.; Guhardja, E.; Gradstein, S.R. Bryophytes on tree trunks in natural forests, selectively logged forests and cacao agroforests in Central Sulawesi, Indonesia. Biol. Conserv. 2008, 141, $2516-2527$. [CrossRef]

37. Sporn, S.G.; Bos, M.M.; Hoffstätter-Müncheberg, M.; Kessler, M.; Gradstein, S.R. Microclimate determines community composition but not richness of epiphytic understory bryophytes of rainforest and cacao agroforests in Indonesia. Funct. Plant Biol. 2009, 36 , 171-179. [CrossRef]

38. Gradstein, S.R.; Sporn, S.G. Land-use change and epiphytic bryophyte diversity in the Tropics. Nova Hedwig. 2010, 138, 311-323. 
39. Ezukanma, I.O.; Tessler, M.; Salaam, A.M.; Chukwuka, K.S.; Ogunniran, A.J. Epiphytic bryophytes of urban agroforests in Ibadan, Southwest Nigeria. J. Bryol. 2019, 41, 341-349. [CrossRef]

40. Gradstein, S.R.; León-Yánez, S. Liverwort diversity in Polylepis pauta forests of Ecuador under different climatic conditions. Neotrop. Biodivers. 2020, 6, 138-146. [CrossRef]

41. Gradstein, S.R.; Pócs, R. Diversity of liverworts and hornworts in Polylepis sericea forests in the Andes of Venezuela. Nova Hedwig. 2021, 112, 49-68. [CrossRef]

42. Gil, J.E.; Morales, M.E. Estratificación vertical de briófitos epífitos encontrados en Quercus humboldtii (Fagaceae) de Boyacá, Colombia. Rev. Biol. Trop. 2014, 62, 719-727.

43. Lencinas, M.V.; Martínez Pastur, G.; Solán, R.; Gallo, E.; Cellini, J.M. Forest management with variable retention impact over bryophyte communities of Nothofagus pumilio understory. Forstarchiv 2008, 79, 77-82.

44. Manríquez, M.D.R.T.; Ardiles, V.; Promis, Á.; Herrera, A.H.; Soler, R.; Lencinas, M.V.; Pastur, G.M. Forest canopy-cover composition and landscape influence on bryophyte communities in Nothofagus forests of southern Patagonia. PLoS ONE 2020, 15, e0232922. [CrossRef]

45. Palacios, B.; Aguirre, Z.; Pucha, D.; Mozha, J.; Armijos, C.; Feijoo, C.; Jumbo, J.; Rojas, A. Factor de forma y productividad de una plantación de Juglans neotropica Diels, establecida en los predios de la Universidad Nacional de Loja. In Memorias I Congreso Internacional de Bosques y Agroforestería; ESPOCH: Riobamba, Ecuador, 2017.

46. Nieto, V.; Rodríguez, J. Juglans neotropica Diels. In Libro Rojo de Plantas de Colombia. Tomo 4; Corporación Nacional de Investigación Forestal: Bogotá, Colombia, 2002; pp. 258-259.

47. Ramírez, F.; Kallarackal, J. The phenology of the endangered Nogal (Juglans neotropica Diels) in Bogota and its conservation implications in the urban forest. Urban Ecosyst. 2021, 1-16. [CrossRef]

48. Aguirre Mendoza, Z.; Reyes Jiménez, B.; Quizhpe Coronel, W.; Cabrera, A. Composición florística, estructura y endemismo del componente leñoso de un bosque montano en el sur del Ecuador. Arnaldoa 2017, 24, 543-556. [CrossRef]

49. Gradstein, S.R.; Churchill, S.P.; Salazar-Allen, N. Guide to the Bryophytes of Tropical America; New York Botanical Garden: Bronx, NY, USA, 2001.

50. Gradstein, S.R.; da Costa, D.P. Hepaticae and Anthocerotae of Brazil; New York Botanical Garden Press: Bronx, NY, USA, 2003.

51. Gradstein, S.R. The Liverworts and Hornworts of Colombia and Ecuador; New York Botanical Garden: Bronx, NY, USA, 2021.

52. Churchill, S.P.; Linares, E.L. Prodomus Bryologie Novo Granatensis. Introducción a la flora de musgos de Colombia; Tomos I y II. Instituto de Ciencias Naturales, Facultad de Ciencias, Universidad Nacional de Colombia: Bogotá, Colombia, 1995.

53. Frazer, G.W.; Canham, C.D.; Lertzman, K.P. Gap Light Analyzer (GLA), Version 2.0. Technological tools. Bull. Ecol. Soc. Am. 2000, 81, 191-197.

54. Zuur, A.F.; Ieno, E.N.; Smith, G.M. Analysing Ecological Data; Statistics for Biology and Health; Springer: New York, NY, USA, 2007.

55. Oksanen, J.; Blanchet, F.G.; Friendly, M.; Kindt, R.; Legendre, P.; Mcglinn, D.; Minchin, P.R.; O’hara, R.B.; Simpson, G.L.; Solymos, P.; et al. Package "vegan". In Community Ecology Package; R Foundation for Statistical Computing: Vienna, Austria, 2019; Available online: https:/ / cran.r-project.org/web/packages/vegan/ (accessed on 17 January 2019).

56. Dufrene, M.; Legendre, P. Species Assemblages and Indicator Species: The Need for a Flexible Asymmetrical Approach. Ecol. Monogr. 1997, 67, 345-366. [CrossRef]

57. Roberts, D.W. Package 'labdsv': Ordination and Multivariate Analysis for Ecology. Version 1.6-1. 2013. Available online: https:/ / cran.r-project.org/web/packages/labdsv/ (accessed on 17 January 2019).

58. R Team Development Core Team. R: A Language and Environment for Statistical Computing; R Foundation for Statistical Computing: Vienna, Austria, 2020.

59. Acebey, A.; Gradstein, S.R.; Krömer, T. Species richness and habitat diversification of bryophytes in submontane rain forest and fallows of Bolivia. J. Trop. Ecol. 2003, 19, 9-18. [CrossRef]

60. Guerra, G.; Arrocha, C.; Rodríguez, G.; Déleg, J.; Benítez, Á. Briófitos en los troncos de los árboles como indicadores de la alteración en bosques montanos de Panamá. Rev. Biol. Trop. 2020, 68, 492-502. [CrossRef]

61. Gradstein, S.R.; Culmsee, H. Bryophyte diversity on tree trunks in montane forests of Central Salawesi, Indonesia. Trop. Bryol. 2010, 31, 95-105.

62. León-Yánez, S.; Valencia, R.; Pitman, N.; Endara, L.; Ulloa Ulloa, C.; Navarrete, H. Libro Rojo de las Plantas Endémicas del Ecuador, 2nd ed.; Publicaciones del Herbario QCA, Pontificia Universidad Católica del Ecuador: Quito, Ecuador, 2011. 